\title{
Research of Hydrogen Preparation with Catalytic Steam-Carbon Reaction Driven by Photo-Thermochemistry Process
}

\author{
Xiaoqing Zhang, ${ }^{1}$ Bingqing Xu, ${ }^{1}$ Yan $X u,{ }^{1}$ Shuyong Shang, ${ }^{1,2}$ and Yongxiang Yin ${ }^{1}$ \\ ${ }^{1}$ School of Chemical Engineering, Sichuan University, Chengdu 610065, China \\ ${ }^{2}$ Institute for Chemical Engineering Technology, Yibin University, Yibin 644007, China \\ Correspondence should be addressed to Yongxiang Yin; hyyx0675@sina.com
}

Received 27 March 2013; Accepted 12 August 2013

Academic Editor: Maria Gomez

Copyright (c) 2013 Xiaoqing Zhang et al. This is an open access article distributed under the Creative Commons Attribution License, which permits unrestricted use, distribution, and reproduction in any medium, provided the original work is properly cited.

\begin{abstract}
An experiment of hydrogen preparation from steam-carbon reaction catalyzed by $\mathrm{K}_{2} \mathrm{CO}_{3}$ was carried out at $700^{\circ} \mathrm{C}$, which was driven by the solar reaction system simulated with Xenon lamp. It can be found that the rate of reaction with catalyst is 10 times more than that without catalyst. However, for the catalytic reaction, there is no obvious change for the rate of hydrogen generation with catalyst content range from $10 \%$ to $20 \%$. Besides, the conversion efficiency of solar energy to chemical energy is more than $13.1 \%$ over that by photovoltaic-electrolysis route. An analysis to the mechanism of catalytic steam-carbon reaction with $\mathrm{K}_{2} \mathrm{CO}_{3}$ is given, and an explanation to the nonbalanced $\left[\mathrm{H}_{2}\right] /\left[\mathrm{CO}+2 \mathrm{CO}_{2}\right]$ is presented, which is a phenomenon usually observed in experiment.
\end{abstract}

\section{Introduction}

Hydrogen is an important energy material to fuel cell and various chemicals such as methanol, dimethyl ether, and synthetic gasoline. The traditional way to obtain hydrogen is to decompose the methane and water, which consumes a lot of other powers such as electricity. Therefore, the technical improvements to make hydrogen generation a cost-effective reality have become challenging subjects.

The sunlight is an inexhaustible and cost-free source of energy. The direct use of solar energy to obtain hydrogen is the most desirable way that has drawn wide attention from energy scientists all over the world [1-4]. There were three ways in the past decades to produce hydrogen by solar energy: photovoltaic-electrolysis (PVE), photoelectrochemistry (PEC), and photo-thermochemistry (PTC). PVE makes use of solar cell to drive electrolysis of water, which is a way to directly convert solar energy into chemical energy [5]. Since the water electrolysis has been a mature technology, PVE process is maturer than the other two solarto-hydrogen processes currently. The PEC makes use of electrochemical reactions [6-8] driven by quantum effects of photoirradiation on semiconductor metal oxide (SMO) catalytic anode which is connected to an external circuit. On the base of optical excitation, the excited electrons on SMO are removed from the anode to cathode through external circuit. The four holes were left in the catalytic anode of SMO, where the water can be split as follows.

$$
2 \mathrm{H}_{2} \mathrm{O} \longrightarrow \mathrm{O}_{2}+4 \mathrm{H}^{+}+4 e \quad E=0.82 \mathrm{~V} \text { at } \mathrm{pH}=7 .
$$

At cathode the $\mathrm{H}^{+}$is reduced

$$
2 \mathrm{H}^{+}+2 e \longrightarrow \mathrm{H}_{2} \quad E=0.41 \mathrm{~V} \text { at } \mathrm{pH}=7,
$$

where $E$ is the reduction potential. The production of hydrogen by PTC uses concentrated solar radiation as the energy source to drive cycle redox reaction at more than $1500 \mathrm{~K}$ [911], such as the pyrogenation of $\mathrm{ZnO} \stackrel{\text { solar }}{\longrightarrow} \mathrm{Zn}+(1 / 2) \mathrm{O}_{2}$ and the oxidation of $\mathrm{Zn}+\mathrm{H}_{2} \mathrm{O} \rightarrow \mathrm{H}_{2}+\mathrm{ZnO}$ by turn.

The energy conversion efficiency (ECE) of solar-tohydrogen is defined as [6]

$$
\eta_{\text {solar-fuel }}=\frac{\Delta H}{Q_{\text {solar }}},
$$

where $Q_{\text {solar }}$ is the solar energy input (in kJ) and $\Delta H$ is the high heating value (HHV) of the fuel produced. The ECE of solar-to-hydrogen by PVE is about $10 \%$, which is 


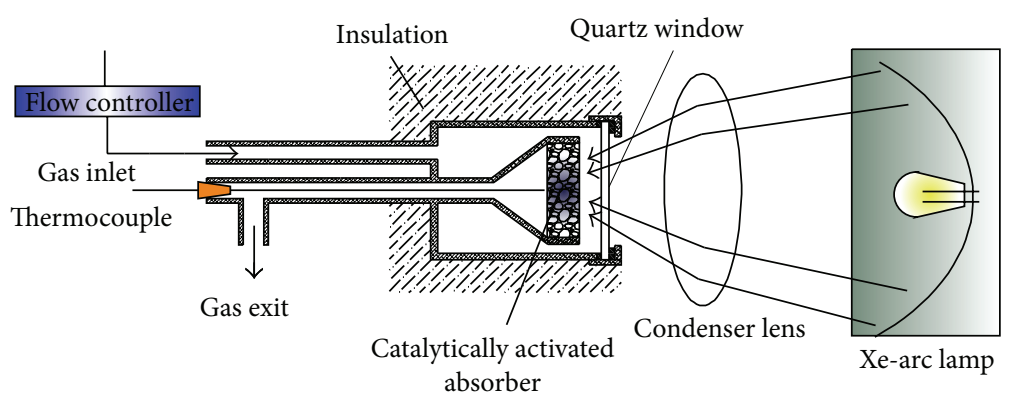

FIGURE 1: Schematic of the main part in experiment.

determined by the efficiencies of solar-to-electricity (17\%) and the water electrolysis (60\%). For photo-electrochemistry, the ECE is determined by the photon energy level in which the electron in catalytic anode is pumped from a donor to an acceptor. The quantum effects to excite electron result in a poor utilization of the solar spectrum and low solar energy conversion efficiency (less than 2\%). In conclusion, the hydrogen production from solar thermochemical cycles is the most desirable path, but the products $\mathrm{Zn}(\mathrm{g})$ and $\mathrm{O}_{2}$ must be quickly quenched at high temperature to avoid their recombination, which inevitably bring the heat loss and result in ECE lower than $10 \%$ in experimental operations.

In fact, there are more simple ways to produce hydrogen by solar energy, for example, the endothermic reactions of

$$
\begin{gathered}
\mathrm{CH}_{4}+\mathrm{CO}_{2} \longrightarrow 2 \mathrm{CO}+2 \mathrm{H}_{2} \quad \Delta H_{298 \mathrm{~K}}=247 \mathrm{~kJ} / \mathrm{mol} \\
\mathrm{C}+\mathrm{H}_{2} \mathrm{O} \longrightarrow \mathrm{CO}+\mathrm{H}_{2} \quad \Delta H_{298 \mathrm{~K}}=119 \mathrm{~kJ} / \mathrm{mol} .
\end{gathered}
$$

These reactions can be achieved at temperature about $700^{\circ} \mathrm{C}$ by catalyst, which is more easily carried out with concentrated solar reactor. Wörner and Tamme [12], Kodama et al. [13], and Berman et al. [14] had achieved many encouraging progresses in the carbon dioxide reforming of methane driven by concentrated solar. They had obtained the solarhydrogen ECE of $45 \%$ on MW levels of solar concentrator with efficiency of solar to heat by $85 \%$.

In this study, the hydrogen was prepared by catalytic steam-carbon reaction at $700^{\circ} \mathrm{C}$, which was driven by a concentrated solar reactor. The generation rate of hydrogen has been investigated with different contents of potassium carbonate. A special attention was paid to the impact of catalyst content and the reaction mechanism onto the energy conversion efficiency over the process.

\section{Experimental}

2.1. Preparation of Feedstock. The feedstock was prepared with equivalent-volume impregnation method. The preweighed potassium carbonate was dissolved with deionized water to obtain the impregnation solution; then the preweighed granular activated carbon with the size of 20 40 meshes $(0.38 \mathrm{~mm} \sim 0.83 \mathrm{~mm})$ was then impregnated in the configured solution for four hours. After that, it was transpired by water bath at $80^{\circ} \mathrm{C}$ and then dried at $110^{\circ} \mathrm{C}$ for more than ten hours to thoroughly remove the moisture. A series of feedstock was prepared with potassium carbonate contents of $0 \%, 10 \%, 15 \%$, and $20 \%$ in weight. The phase and morphology of the typical feedstock were characterized by $\mathrm{X}$-ray diffraction (XRD, Dandong, China, $\mathrm{Cu} / \mathrm{K} \alpha$ radiation, voltage: $40 \mathrm{kV}$, current: $25 \mathrm{~mA}$; scanning rate: $2^{\circ} / \mathrm{min}$; scan range: $2 \theta=30^{\circ} \sim 80^{\circ}$ ) and transmission electron microscopy (Tecnai G2 F20 S-TWIN, USA, voltage: $200 \mathrm{KV}$ ).

2.2. Experimental Arrangement. Figure 1 shows the main part of the experimental facility; it consists of the simulated solar concentrator and the reactor. The reactor included a tundishlike reaction bed in diameter of $40 \mathrm{~mm}$, where the feedstock was filled. Temperature in reaction bed was monitored by a thermocouple. The solar concentrator was simulated by focusing Xe-lamp irradiation. The facular diameter at reaction bed was about $3 \mathrm{~cm}$. The energy flux onto the reaction bed was measured by LJ-II laser power meter (Chinese testing technology research institution). Changing the input power of Xenon lamp could adjust the value of energy flux. The typical average energy flux of $120.1 \mathrm{KW} / \mathrm{m}^{2}$ could be obtained with the Xenon lamp powered $1000 \mathrm{~W}$, at which the reaction bed temperature was about $700^{\circ} \mathrm{C}$ for experiments.

Figure 2 is the flow chart of the experiment. After argon of $60 \mathrm{~mL} / \mathrm{min}$ purged the air in reaction bed filled with feedstock, heating the temperature of reactor to $700^{\circ} \mathrm{C}$. Then the micropump was turned on, and the water was fed into steam generator. The steam carried by argon of $60 \mathrm{~mL} / \mathrm{min}$ was fed into reaction bed, where the steam-carbon reaction took place. The exiting gases through washing, condensation, and drying were then analyzed by gas chromatograph (GC7900, using TDX-01 packed column $3 \mathrm{~mm} \times 2 \mathrm{~mm}$ and TCD detector). The gas flow was measured by a bubo soapfilm flowmeter.

Each experiment with different potassium carbonate was carried out at the same conditions: temperature of $700^{\circ} \mathrm{C}$, water rate of $0.27 \mathrm{~mL} / \mathrm{min}$, feedstock of $1.2 \mathrm{~g}$, and reaction time of 45 minutes.

2.3. Data Treatment. The main reaction of steam with active carbon is

$$
\mathrm{C}+\mathrm{H}_{2} \mathrm{O} \longrightarrow \mathrm{CO}+\mathrm{H}_{2} \quad \Delta H_{298 \mathrm{~K}}=119 \mathrm{~kJ} / \mathrm{mol},
$$




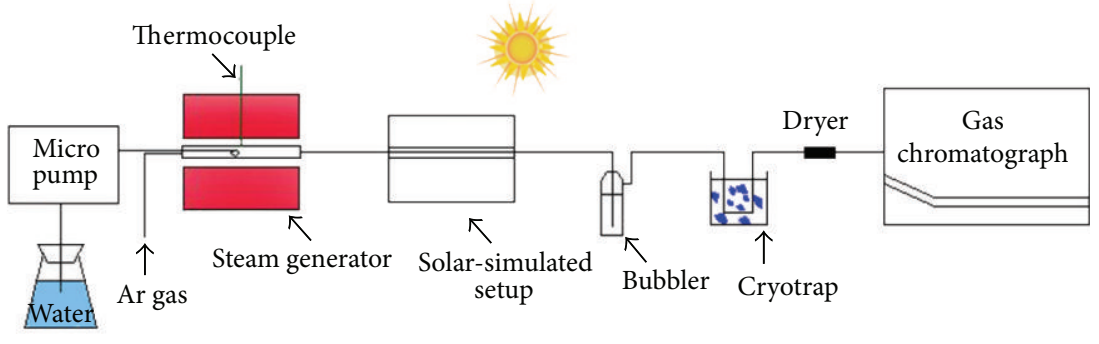

Figure 2: Experimental flow diagram.

and the incidental reactions are

$$
\begin{gathered}
\mathrm{CO}+\mathrm{H}_{2} \mathrm{O} \longrightarrow \mathrm{CO}_{2}+\mathrm{H}_{2} \quad \Delta H_{298 \mathrm{~K}}=-42 \mathrm{~kJ} / \mathrm{mol} \\
\mathrm{C}+\mathrm{CO}_{2} \longrightarrow 2 \mathrm{CO} \quad \Delta H_{298 \mathrm{~K}}=162 \mathrm{~kJ} / \mathrm{mol} .
\end{gathered}
$$

The conversion rate of carbon was defined as

$$
X(\mathrm{C})=\frac{\left(N_{\mathrm{CO}}+N_{\mathrm{CO}_{2}}\right)}{N_{\mathrm{C} . \mathrm{in}}} \times 100 \% \text {, }
$$

where $N_{\mathrm{CO}}$ and $\mathrm{N}_{\mathrm{CO}_{2}}$ are the releasing cumulants (in moles) of $\mathrm{CO}$ and $\mathrm{CO}_{2}$ with reaction process, respectively, and the $N_{\text {C.in }}$ is the primary moles of activated carbon. To estimate the efficiency of optical energy served in chemical energy, according to reference [6], the energy conversion efficiency of the present process is redefined as

$$
\eta=\frac{\sum H_{\mathrm{out}}^{i}-\sum H_{\mathrm{in}}^{i}}{\rho \cdot S \cdot t}
$$

where $H_{\text {out }}^{i}, H_{\text {in }}^{i}$ are the high heating values (HHVs) of the fuel produced and exhausted in reaction process, respectively; $\rho$ the average energy flux at catalysis bed; $S$ the facular area; $t$, the reaction time.

\section{Results and Discussion}

3.1. Performance of Steam-Carbon Reactions with Different Catalyst Contents. In order to evaluate the catalytic performance of potassium carbonate in steam-carbon reaction, the experiments with different catalyst contents of $0,10 \%, 15 \%$, and $20 \%$ were carried out; the results are shown in Figure 3.

It can be found that there is an obvious difference between noncatalytic steam-carbon reaction and catalytic reaction. In the initial stage, the generation rate of hydrogen and carbon monoxide is about ten times to that without potassium carbonate, but there is less difference among that with potassium carbonate contents of $10 \%, 15 \%$, and $20 \%$. Similar results were also found in steam gasification of coal char catalyzed with $\mathrm{K}_{2} \mathrm{CO}_{3}$ by Wang et al. [15], where, at catalyst loading lower than $7.5 \%$, the gasification was slow even with prolonged gasification time. Both observations are in agreement with that the catalyst is activated in steamcarbon reaction only when the initial potassium carbonate loading is larger than a threshold value, above which the catalytic activity is obvious, but less difference in its content larger than $10 \%$ [16]. The changes of generation rates with time can be explained by the model of core shrinkage. In the initial stage of reaction, the surface of solid reactant is bigger than that in the later stage because of the carbon exhausted. There are more molecular contacts between steam and carbon, which leads to more reactions.

By Figures 3(b) and 3(c), though the generation rate of $\mathrm{CO}_{2}$ takes on the trend of initial increase and then decrease, the ratio of $\mathrm{CO}_{2} / \mathrm{CO}$ increases throughout the reaction process. This can be understood with the competition between (7) and (8). It can be conjectured that (7) is a gaseous volume reaction, in which the reaction possibility is constant; while (8) is a surface reaction on carbon, its reaction possibility is impacted by the surface of solid reactant. In the initial stage, there is more carbon existent; it makes reaction (8) consume $\mathrm{CO}_{2}$ and the reaction possibility of (8) become less and less in the later stage of reaction because of the carbon exhausted.

It is worth noticing the ratio of $\left[\mathrm{H}_{2}\right] /\left[\mathrm{CO}+2 \mathrm{CO}_{2}\right]$ from experimental results. Assuming that all $\mathrm{H}_{2}$ is generated via reactions (6) and (7), the ratio would be equal to 1 . The actual ratio estimated in Figure 3 is somewhat greater than 1 in the initial 20 minutes, only in the middle stage is matching in the estimation, and then below the estimation in the last stage. However, the average $\left[\mathrm{H}_{2}\right] /\left[\mathrm{CO}+2 \mathrm{CO}_{2}\right]$ ratios are close to the estimation as reported by [15]. The reason for this observation will be discussed in Section 3.3.

Figures 4(a) and 4(b) show the carbon conversion and hydrogen yield calculated by cumulant with time over the reaction process, respectively. Figure 4(c) is the energy conversion efficiency calculated by (10). At the initial stage, the ECE is $27.6 \%$. With time passing, the carbon exhausted and the reaction rate decreased, the ECE reached and $13.1 \%$ in the end of experiments. However, it is still larger than $10.89 \%$ by photovoltaic-electrolysis method.

3.2. TEM and XRD Analysis of Reactants. The TEM and XRD results were shown in Figures 5 and 6 , respectively. The dark part in Figure 5 is regarded as $\mathrm{K}_{2} \mathrm{CO}_{3}$ crystalloid, which was randomly distributed in or on the active carbon clusters. Because the active carbon is amorphous, only the characteristic diffraction of $\mathrm{K}_{2} \mathrm{CO}_{3}$ can be detected with the samples before and after reactions. It proves the $\mathrm{K}_{2} \mathrm{CO}_{3}$ acts as a catalyst in experiments.

3.3. Mechanism of Steam-Carbon Reaction Catalytic by $\mathrm{K}_{2} \mathrm{CO}_{3}$. Moulijn and Kapteijn [17] have presented a theory 


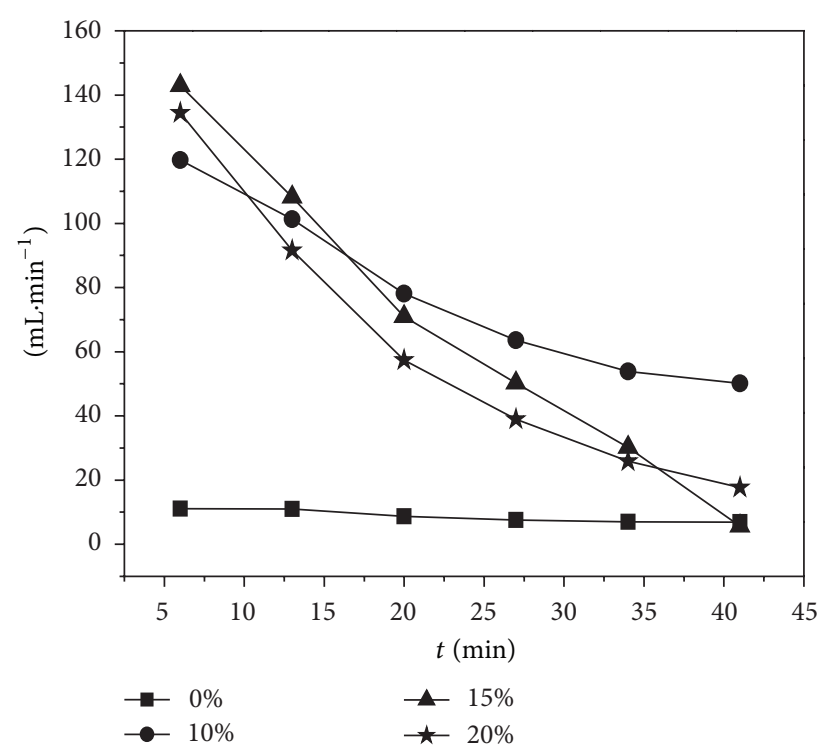

(a)

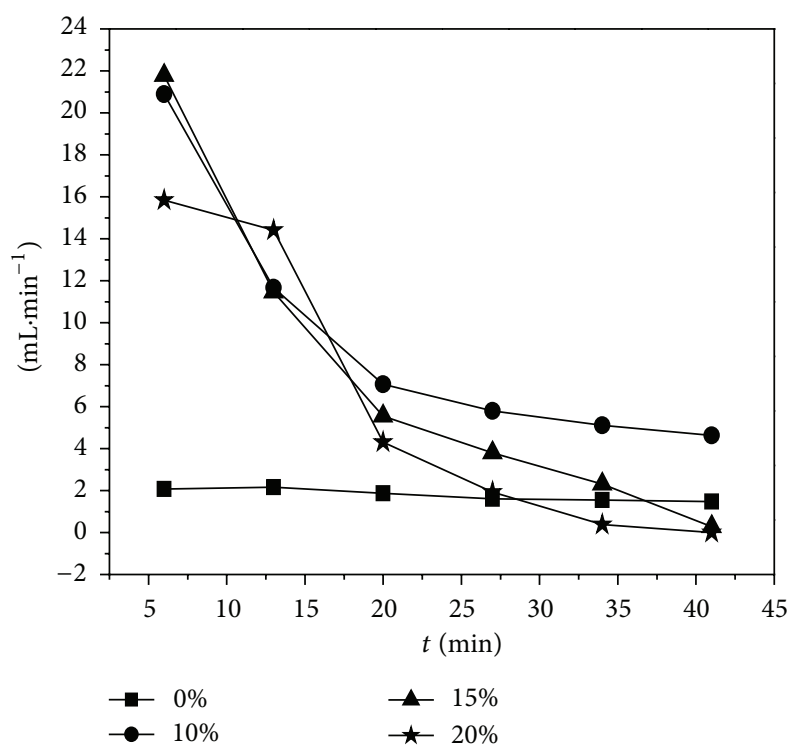

(b)

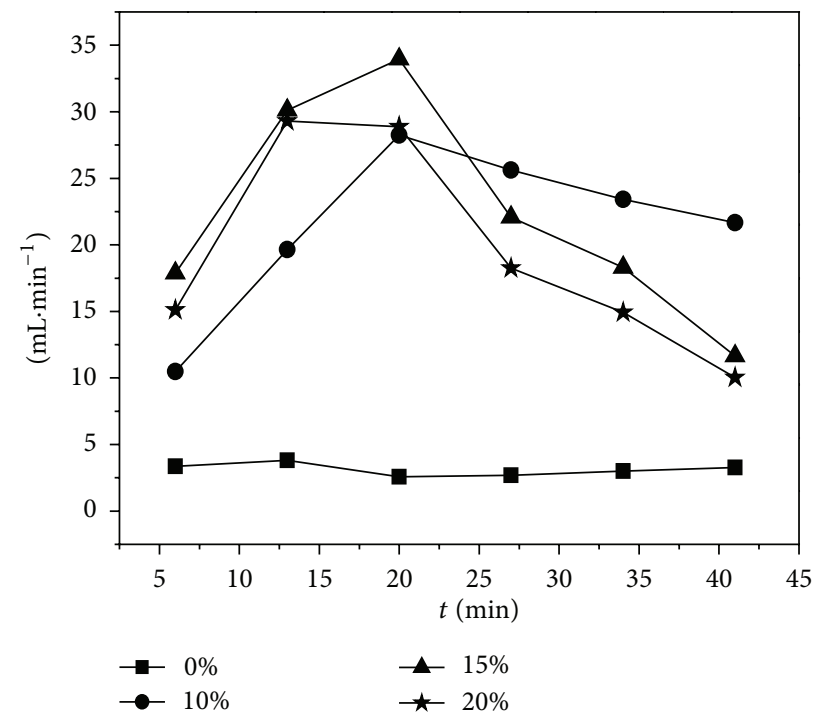

(c)

FIGURE 3: The generation rate versus time in experiments with different catalyst contents. (a) Hydrogen, (b) carbon monoxide, and (c) carbon dioxide.

to describe the mechanism of noncatalytic gasification of carbon. They considered that there were some chemically active sites formed by the lacunas or unsaturated carbon chains on carbon surface, which had ability to adsorb oxygenic atoms. In the steam-carbon reaction, the $\mathrm{H}_{2} \mathrm{O}$ molecular was adsorbed by those active sites to form $\mathrm{C}_{\mathrm{r}}(\mathrm{O})$ intermediates and release $\mathrm{H}_{2}$. Then the $\mathrm{C}_{\mathrm{r}}(\mathrm{O})$ intermediates ran away from solid carbon by their thermal motion at high temperature, and a newborn site was left. The process can be expressed as follows:

$$
\begin{gathered}
\mathrm{C}_{\mathrm{r}}+\mathrm{H}_{2} \mathrm{O} \longrightarrow \mathrm{C}_{\mathrm{r}}(\mathrm{O})+\mathrm{H}_{2} \\
\mathrm{C}_{\mathrm{r}}(\mathrm{O})+\mathrm{C} \longrightarrow \mathrm{CO}+\mathrm{C}_{\mathrm{r}} .
\end{gathered}
$$

The calculation of quantum mechanics by Wjgmans et al. [18] should told that there would be formed C-O-M clusters when alkali metals oxides (AMO) were soaked on carbon surface by the function of AMO attracted electron. The valence electron of carbon atom close to AMO would tend to AMO and then result in those carbons with positive electricity to trap chemically oxygenated chemicals to form $\mathrm{C}_{\mathrm{r}}(\mathrm{O})$ intermediates.

Considering from the above, the catalytic reaction of steam-carbon by $\mathrm{K}_{2} \mathrm{CO}_{3}$ can be conjectured. During the reactor bed at $700^{\circ} \mathrm{C}$, the $\mathrm{K}_{2} \mathrm{CO}_{3}$ firstly decomposed into $\mathrm{K}_{2} \mathrm{O}$ and $\mathrm{CO}_{2} ; \mathrm{K}_{2} \mathrm{O}$ then functioned according to the route shown in Figure 7 when steam was added in. 


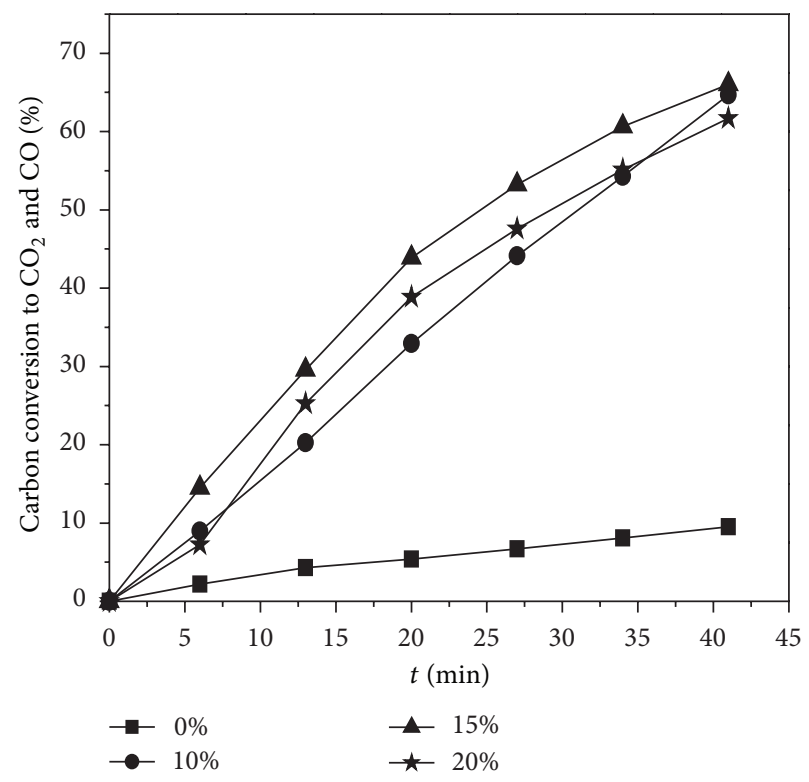

(a)

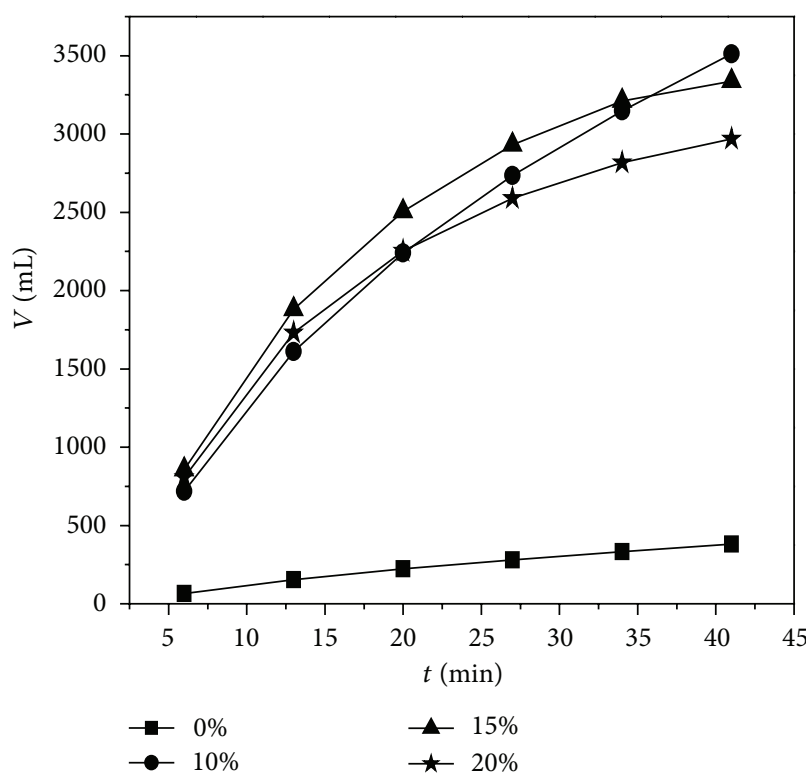

(b)

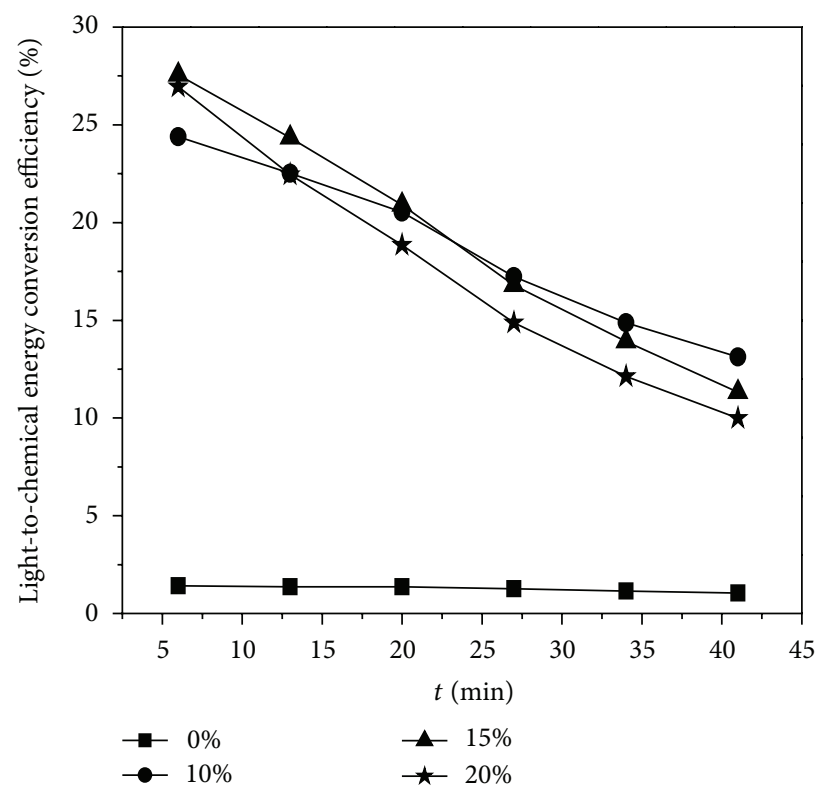

(c)

FIGURE 4: (a) Carbon conversation; (b) hydrogen production; (c) energy conversation efficiency during reaction. follows:

Therefore, the catalytic process can be expressed as

$$
\begin{gathered}
\mathrm{K}_{2} \mathrm{CO}_{3}+\mathrm{C}_{\mathrm{r}} \longrightarrow \mathrm{K}_{2} \mathrm{O}+\mathrm{CO}_{2}+\mathrm{C}_{\mathrm{r}} \\
\mathrm{C}_{\mathrm{r}}+\mathrm{H}_{2} \mathrm{O} \stackrel{\mathrm{K}_{2} \mathrm{O}}{\longrightarrow} \mathrm{C}_{\mathrm{r}}(\mathrm{O})+\mathrm{H}_{2} \\
\mathrm{C}_{\mathrm{r}}(\mathrm{O})+\mathrm{C} \longrightarrow \mathrm{CO}+\mathrm{C}_{\mathrm{r}} .
\end{gathered}
$$

By this way, the catalytic effects of $\mathrm{K}_{2} \mathrm{O}$ on steam-carbon reaction could be concluded in two aspects: one is to provide the amount of active sites on carbon surface; another is to decrease the activated energy to form $\mathrm{C}_{\mathrm{r}}(\mathrm{O})$ intermediates.
The steam-carbon gasification is a heterogeneous catalytic reaction. It involves the adsorption, diffusion, reaction, and desorption on gas-solid surface. In the initial stage, the bigger precursor surface can provide many active sites. It makes chemical adsorption for $\mathrm{H}_{2} \mathrm{O}$ molecular at these sites to release oxygen atoms and $\mathrm{H}_{2}$. The $\mathrm{C}_{\mathrm{r}}(\mathrm{O})$ intermediates were formed by these oxygen atoms and left from surface by their thermal motion. If the reaction temperature is not high enough, the $\mathrm{C}_{\mathrm{r}}(\mathrm{O})$ intermediates could not leave in time. Therefore, the ratio of $\left[\mathrm{H}_{2}\right] /\left[\mathrm{CO}+2 \mathrm{CO}_{2}\right]$ is larger than 1 in the initial stage. When the $\mathrm{C}_{\mathrm{r}}(\mathrm{O})$ intermediates reached saturation on carbon surface, the ratio is less than 


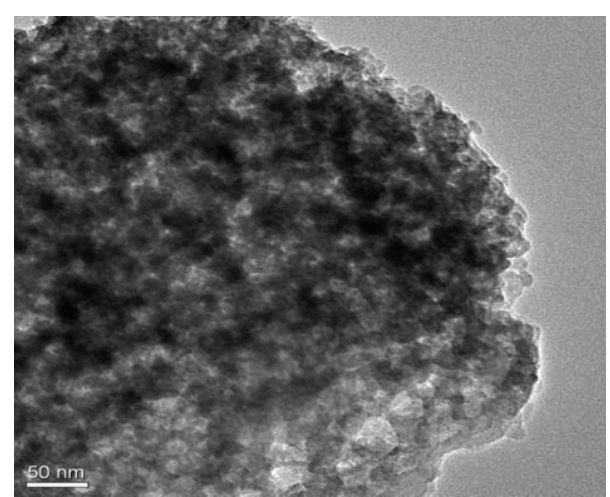

FIGURE 5: TEM images of feedstock.

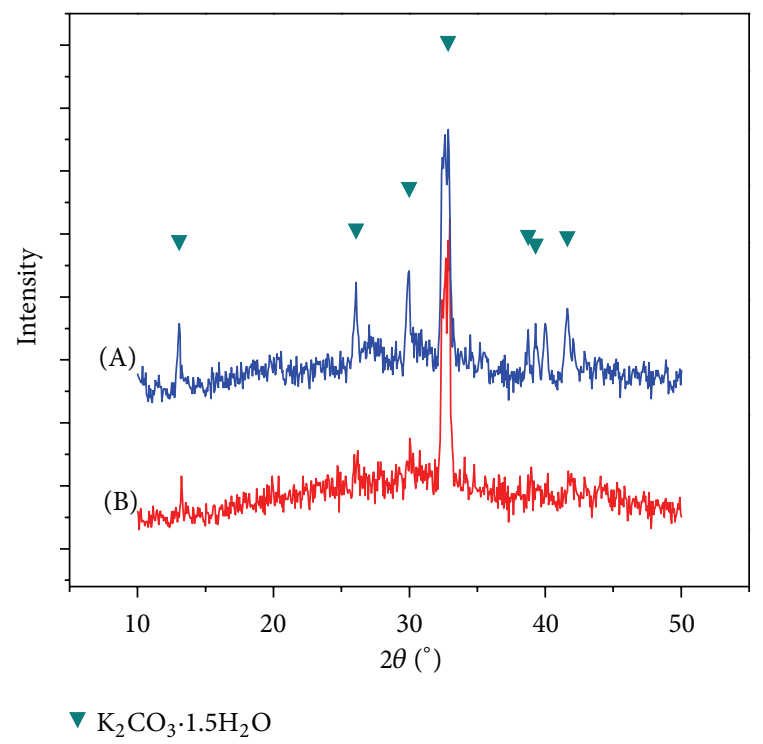

FIGURE 6: XRD patterns of the feedstock with $\mathrm{K}_{2} \mathrm{CO}_{3}$ of $10 \%$ : (a) before reaction; (b) after reaction.

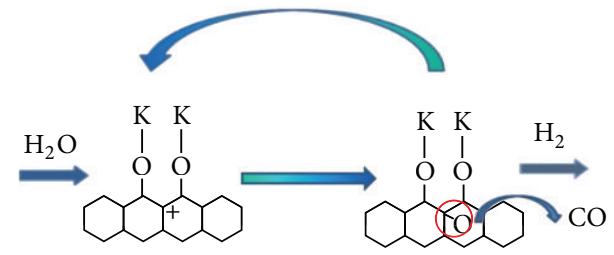

FIGURE 7: $\mathrm{H}_{2} \mathrm{O}-\mathrm{C}$ catalytic reaction schematic diagram.

1 in the latter stage. This can be the reason why the $\mathrm{C}_{\mathrm{r}}(\mathrm{O})$ intermediates run away from surface in the controlling step of steam-carbon reaction, which was observed in many experiments.

\section{Conclusions}

The hydrogen preparation experiment was carried out with catalytic steam-carbon reaction driven by simulated solar energy, and the observations in experiments were analyzed.
There is something that can be concluded: with the $\mathrm{K}_{2} \mathrm{CO}_{3}$ catalyst, the reaction is achieved at temperature of $700^{\circ} \mathrm{C}$, and the conversion efficiency of optical energy to chemical energy is more than $13.1 \%$ over that by photovoltaic-electrolysis route. The catalytic mechanism of steam-carbon reaction with $\mathrm{K}_{2} \mathrm{CO}_{3}$ was that the $\mathrm{K}_{2} \mathrm{CO}_{3}$ firstly decomposed into $\mathrm{K}_{2} \mathrm{O}$ at higher temperature; then the $\mathrm{K}_{2} \mathrm{O}-\mathrm{C}^{+}$clusters were formed by the charge center displacement which was caused by electron interaction between $\mathrm{K}_{2} \mathrm{O}$ and neighboring $\mathrm{C}$ atom. The $\mathrm{H}_{2} \mathrm{O}$ was chemically adsorbed at $\mathrm{K}_{2} \mathrm{O}-\mathrm{C}^{+}$sites to form $\mathrm{C}_{\mathrm{r}}(\mathrm{O})$ intermediates and released $\mathrm{H}_{2}$ at the same time, and the $\mathrm{C}_{\mathrm{r}}(\mathrm{O})$ intermediates were broken loose from carbon chain by their thermal motion; then a newborn site was left. This cycle repeated itself until the end of reaction.

\section{Acknowledgments}

This study is sponsored by the National Nature Science Foundation of China (Grant no. 11075113). The authors express thanks to the program and thanks for Analysis and Testing Center of Sichuan University for supporting this study.

\section{References}

[1] T. M. Nenoff, M. R. Berman, and K. C. Glasgow, "Introduction to the special section on alternative energy system: hydrogen, solar, and biofuels," Industrial \& Engineering Research, vol. 51, no. 37, pp. 11819-11920, 2012.

[2] Y. Izumi, "Recent advances in the photocatalytic conversion of carbon dioxide to fuels with water and/or hydrogen using solar energy and beyond," Coordination Chemistry Reviews, vol. 257, no. 1, pp. 171-186, 2013.

[3] R. Manuel and S. Aldo, "Concentrating solar thermal power and thermochemical fuels," Energy \& Environmental Science, vol. 5, no. 11, pp. 9234-9245, 2012.

[4] L. J. Guo, L. Zhao, D. W. Jing et al., "Solar hydrogen production and its development in China," Energy, vol. 34, no. 9, pp. 10731090, 2009.

[5] C. C. Agrafiotis, C. Pagkoura, S. Lorentzou, M. Kostoglou, and A. G. Konstandopoulos, "Hydrogen production in solar reactors," Catalysis Today, vol. 127, no. 1-4, pp. 265-277, 2007.

[6] P. Greg, Smestad, and A. Steinfeld, "Review: photochemical and thermochemical production of solar fuels from $\mathrm{H}_{2} \mathrm{O}$ and $\mathrm{CO}_{2}$ using metal oxide catalysts," Industrial and Engineering Chemistry Research, vol. 51, no. 37, pp. 11828-11840, 2012.

[7] Z. Huang and Y. V. Geletii, "Spectroscopic studes of light-driven water oxidation catalyzed by polyoxometalates," Industrial \& Engineering Chemisry Research, vol. 51, no. 37, pp. 11850-11859, 2012.

[8] R. Amadelli, A. Molinari, I. Vitali, L. Samiolo, G. M. Mura, and A. Maldotti, "Photo-electro-chemical properties of $\mathrm{TiO}_{2}$ mediated by the enzyme glucose oxidase," Catalysis Today, vol. 101, no. 3-4, pp. 397-405, 2005.

[9] S. Z. Baykara, "Experimental solar water thermolysis," International Journal of Hydrogen Energy, vol. 29, no. 14, pp. 1459-1469, 2004.

[10] C. Agrafiotis, M. Roeb, A. G. Konstandopoulos et al., "Solar water splitting for hydrogen production with monolithic reactors," Solar Energy, vol. 79, no. 4, pp. 409-421, 2005. 
[11] T. Kodama and N. Gokon, "Thermochemical cycles for hightemperature solar hydrogen production," Chemical Reviews, vol. 107, no. 10, pp. 4048-4077, 2007.

[12] A. Wörner and R. Tamme, " $\mathrm{CO}_{2}$ reforming of methane in a solar driven volumetric receiver-reactor," Catalysis Today, vol. 46, no. 2-3, pp. 165-174, 1998.

[13] T. Kodama, H. Ohtake, K.-I. Shimizu, and Y. Kitayama, "Nickel catalyst driven by direct light irradiation for solar $\mathrm{CO}_{2}$ reforming of methane," Energy and Fuels, vol. 16, no. 5, pp. 10161023, 2002.

[14] A. Berman, R. K. Karn, and M. Epstein, "A new catalyst system for high-temperature solar reforming of methane," Energy and Fuels, vol. 20, no. 2, pp. 455-462, 2006.

[15] J. Wang, M. Jiang, Y. Yao, Y. Zhang, and J. Cao, "Steam gasification of coal char catalyzed by $\mathrm{K}_{2} \mathrm{CO}_{3}$ for enhanced production of hydrogen without formation of methane," Fuel, vol. 88, no. 9, pp. 1572-1579, 2009.

[16] J. Wang, K. Sakanishi, I. Saito, T. Takarada, and K. Morishita, "High-yield hydrogen production by steam gasification of HyperCoal (ash-free coal extract) with potassium carbonate: comparison with raw coal," Energy and Fuels, vol. 19, no. 5, pp. 2114-2120, 2005.

[17] J. A. Moulijn and F. Kapteijn, "Towards a unified theory of reactions of carbon with oxygen-containing molecules," Carbon, vol. 33, no. 8, pp. 1155-1165, 1995.

[18] T. Wigmans, R. Elfring, and J. A. Moulijn, "On the mechanism of the potassium carbonate catalysed gasification of activated carbon: the influence of the catalyst concentration on the reactivity and selectivity at low steam pressures," Carbon, vol. 21, no. 1, pp. 1-12, 1983. 

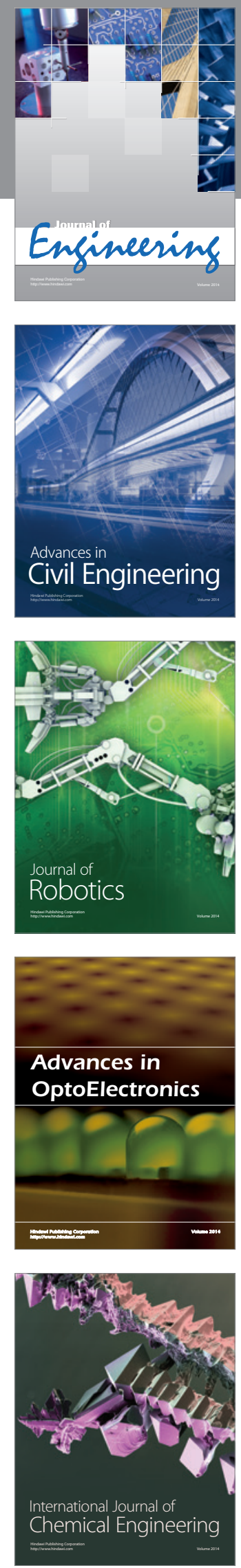

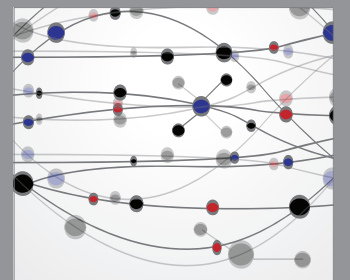

The Scientific World Journal
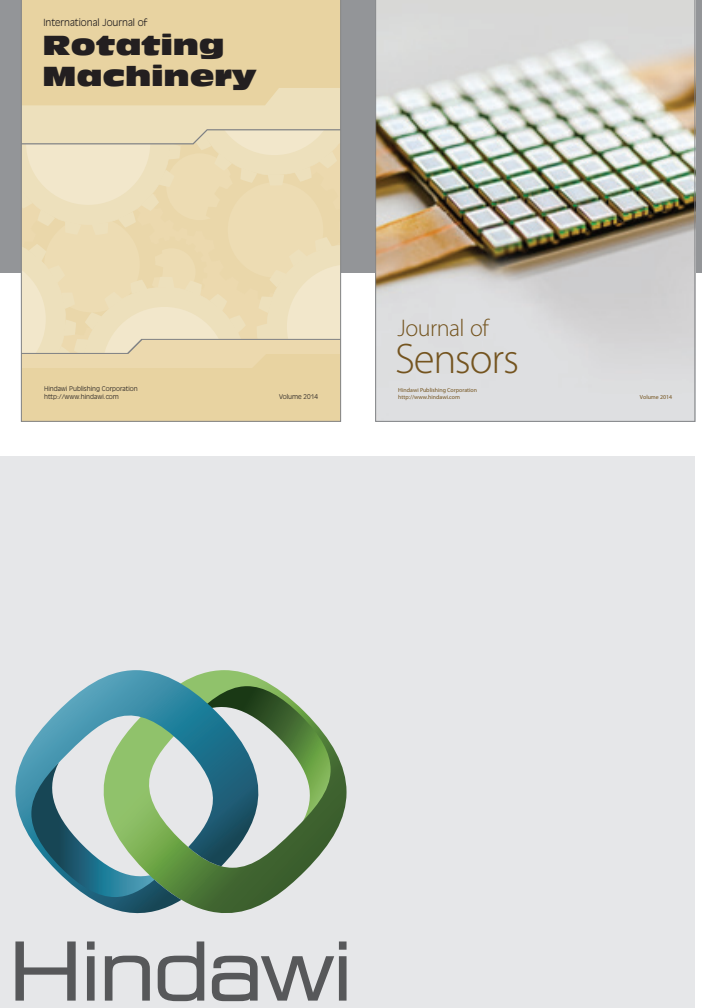

Submit your manuscripts at http://www.hindawi.com
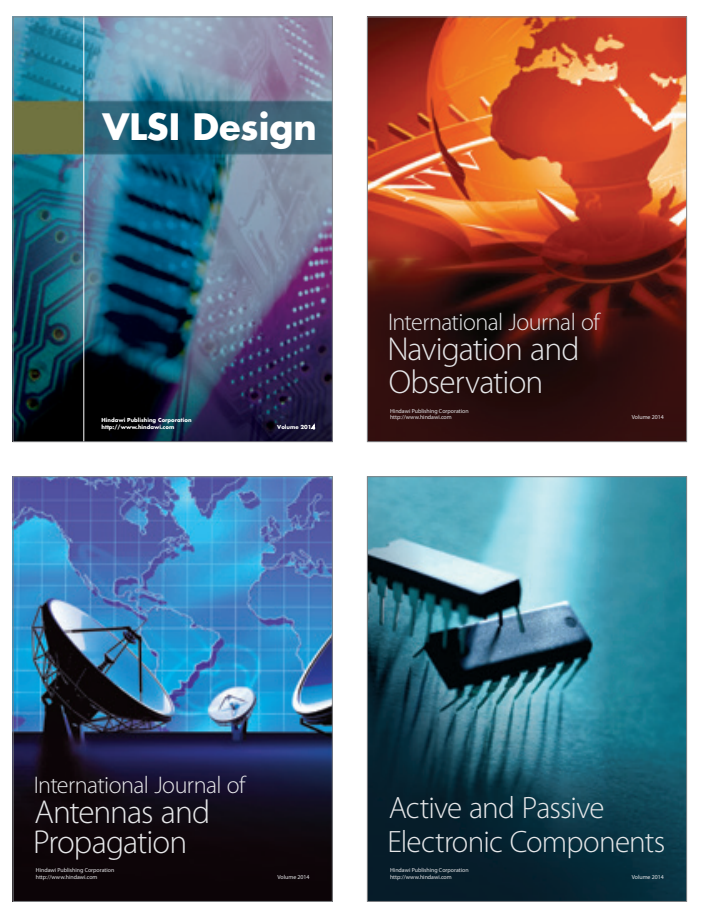
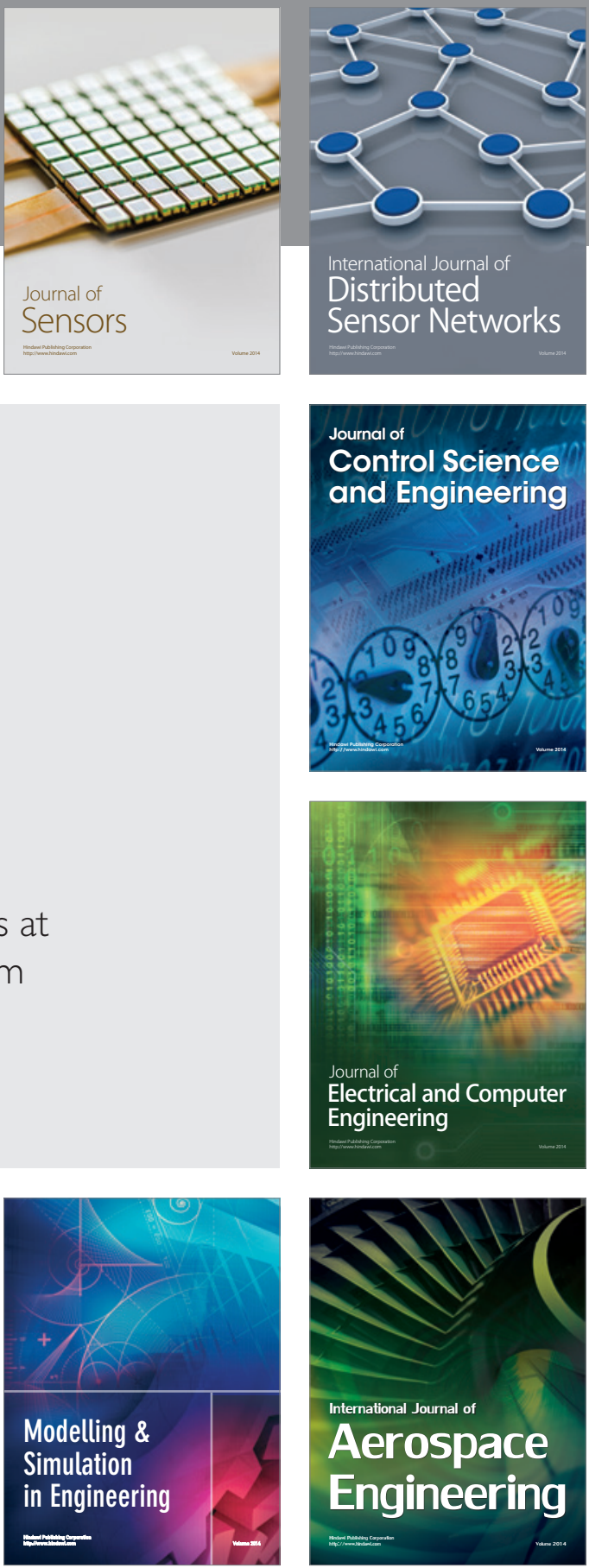

Journal of

Control Science

and Engineering
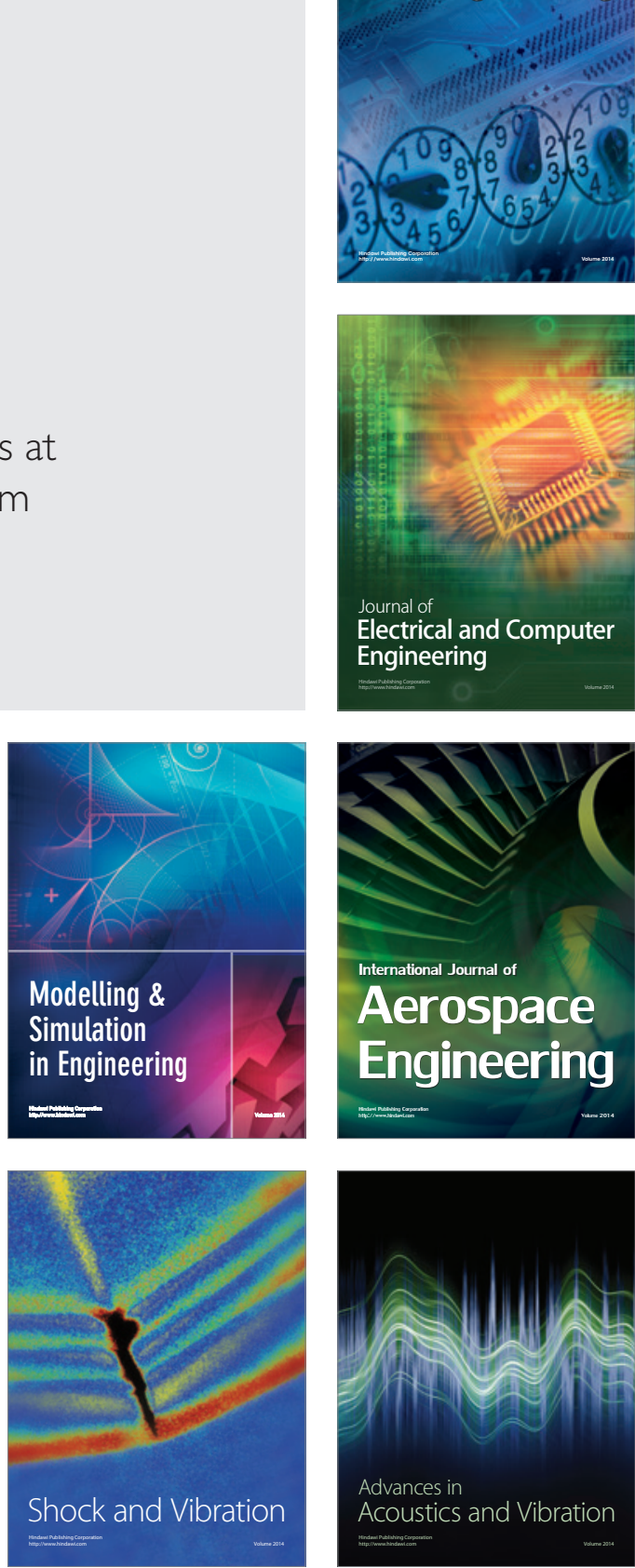